\title{
PERANAN ORGANISASI MASYARAKAT SADAR WISATA (MASATA) UNTUK PENGEMBANGAN DESA WISATA DI KALIMANTAN TIMUR
}

\author{
Sabalius Uhai io \\ Usaha Perjalanan Wisata, Politeknik Negeri Samarinda \\ J1. Ciptomangunkusumo Kampus Gunung Panjang, Kota Samarinda, kodepos 75131 \\ E-mail : sabaliusuhai@polnes.ac.id ${ }^{1)}$
}

\begin{abstract}
ABSTRAK
Organisasi Masyarakat Sadar Wisata (MASATA) adalah sebuah organisasi non profit pariwisata tetapi juga mitra pemerintah dalam upaya mengembangkan pariwisata Indonesia. Mitra pemerintah dalam hal pengawasan program dan kebijakan agar sampai di masyarakat tepat guna dan tepat sasaran. Adapun tujuan dari penelitian ini adalah untuk mengetahui peranan Organisasi Masyarakat Sadar Wisata (MASATA) Kalimantan Timur untuk mengembangkan desa wisata mulai dari melihat potensi, produk, Peluang, pelayanan, profit. Memang ini bukan sebuah pekerjaan yang mudah perlu ada kerja sama semua pihak dalam hal mengembangkan desa wisata. Organisasi Masyarakat Sadar Wisata mempunyai peran yang menghubungkan dengan berbagai pihak untuk saling mendukung, membantu dalam usaha mengembangkan desa wisata. Dalam Organisasi Masyarakat Sadar Wisata (MASATA) memiliki pengurus dari berbagai latar belakang yakni para pecinta budaya, pemerhati pariwisata, organisasi kepariwisataan, peneliti, pendidik, dari kalangan masyarakat yang cinta pariwisata. Metode yang digunakan dalam penelitian ini adalah wawancara secara mendalam (dept interview). Peran dari Organisasi MASATA adalah untuk membantu pengembangan desa wisata, melakukan pendampingan dan mempersiapkan sumber daya manusia di desa wisata yang menjadi pendampingan dari DPD MASATA Kalimantan Timur.
\end{abstract}

Kata Kunci: Peranan MASATA, potensi wisata, desa wisata, pembinaan desa wisata

\section{PENDAHULUAN}

Pariwisata merupakan salah satu sektor industri yang penting dan mempunyai potensi serta peluang yang besar untuk dikembangkan. Perkembangan pariwisata di negara-negara berkembang termasuk Indonesia diharapkan dapat membantu menyamakan peluang ekonomi serta menghambat penduduk desa untuk bermigrasi ke kota. Perkembangan pariwisata juga diharapkan mampu meningkatkan perekonomian sehingga dapat meningkatkan kesejahteraan dimana pariwisata tersebut dikembangkan (Evita, R., Sirtha, I. N., \& Sunarta, 2012).

Menurut UU No. 6 Tahun 2014, desa adalah kesatuan masyarakat hukum yang mempunyai batas wilayah yang berwenang untuk mengatur dan mengurus urusan pemerintahan, kepentingan masyarakat setempat berdasarkan prakarsa masyarakat, hak asal usul, dan/atau hak tradisional yang diakui dan dihormati dalam sistem pemerintahan Negara Kesatuan Republik Indonesia. Menurut Rifhi Siddiq dalam buku Pengantar Pemerintahan Desa desa (Rahayu, 2018) adalah suatu wilayah yang memiliki tingkat kepadatan rendah yang dihuni oleh penduduk dengan interaksi sosial yang bersifat homogen, bermata pencaharian di bidang agraris dan juga mampu berinteraksi dengan wilayah lain di sekitarnya (Abdillah, 2020). Sedangkan Menurut R. Bintarto desa (Rahayu, 2018) yaitu perwujudan atau kesatuan sosial, ekonomi, geografi, politik, serta kultural yang ada di suatu daerah dalam hubungan dan pengaruhnya secara timbal balik dengan daerah lain. Dan selanjutnya pengertian desa menurut Menurut Sutardjo Kartohadikusumo desa adalah suatu kesatuan hukum yang di dalamnya bertempat tinggal sekelompok masyarakat yang berkuasa mengadakan pemerintahan sendiri (Abdillah, 2020). Suatu kawasan dikatakan dapat menjadi desa wisata harus memperhatikan beberapa faktor-faktor. Faktor kelangkaan adalah sifat dari atraksi wisata yang tidak bias dijumpai atau langka di tempat lain. Faktor kealamiahan adalah sifat atraksi wisata yang belum pernah mengalami perubahan akibat campur tangan manusia. Keunikan, yakni sifat atraksi wisata yang memiliki keunggulan komparatif dibanding objek wisata lain.

Kelompok sadar wisata memiliki peran yang sangat penting dalam upaya untuk mengembangkan desa wisata. Salah satu syarat untuk mendirikan desa wisata adalah terbentuknya kelompok sadar wisata atau lebih dikenal dengan istilah pokdarwis. Pembentukan pokdarwis yang baik jika terbentuk muncul dari kesadaran masyarakat desa itu sendiri. Berdasarkan pedoman kelompok sadar wisata yang dikeluarkan oleh Direktur Jenderal Pengembangan Destinasi Pariwisata Kementerian Pariwisata (Dirjen Pengembangan Destinasi Pariwisata, 2012), adapun tujuan pendirian pokdarwis adalah: 
pertama Meningkatkan posisi dan peran masyarakat sebagai subjek atau pelaku penting pembangunan kepariwisataan, serta dapat bersinergi dan bermitra dengan pemangku kepentingan terkait dalam meningkatkan kualitas perkembangan kepariwisataan di daerah. Kedua Membangun dan menumbuhkan sikap dan dukungan positif masyarakat sebagai tuan rumah melalui perwujudan nilai-nilai Sapta Pesona bagi tumbuh dan berkembangnya kepariwisataan di daerah dan manfaatnya bagi pembangunan daerah maupun kesejahteraan masyarakat. Ketiga Memperkenalkan, melestarikan dan memanfaatkan potensi daya tarik wisata yang ada di masing-masing daerah.

Kelompok sadar wisata memiliki strategi dalam mengembangkan pariwisata di desa wisata (Nurmayasari, Dhea, 2017), (Karini, Zulia, Hendra Marcos, 2018), (Wahyuni, 2018). Pemberdayaan pokdarwis (Hakim, Nasrul, Hayati, Suci, Lumbu, Aliyanti A., Nur Indah, Rahmawati \& Septiyana, 2017). Kelompok sadar wisata yang mau belajar dan mempersiapkan diri mereka menjadi lebih baik (Wijaya, Surya Arif, Zulkarnain, 2016), (Andiani, Nyoman Dini, 2017). Kelompok sadar wisata perlu menggali peluang ekonomi kreatif (Vuspitasari, Bendhikta Kikky Deffrinica, 2021). Pokdarwis sebagai penguat desa wisata (Purwanti, 2019). Kelompok sadar wisata adalah penggerak dalam proses pengembangan desa wisata sekaligus melaksanakan program kegiatan pelatihan yang telah anggota kelompok sadar wisata ikuti, pelatihan yang diikuti baik yang diselenggarakan oleh perusahaanperusahaan swasta, perusahaan-perusahaan pemerintah, dinas pariwisata dan perguruan tinggi (Putri, Tiara Nur Tsofyani, Hartuti Purnaweni, 2015), (Utami, Asri Nurul, 2017), (Bona P. Benazir, 2017).

Organisasi Masyarakat Sadar Wisata (MASATA) sebuah organisasi baru yang terbentuk pada tanggal 04 April tahun 2018. Saat itu para pengusaha industri pariwisata Indonesia berkumpul di Denpasar Bali untuk membahas tentang kemajuan pariwisata Indonesia (Sarungu, 2021). Perkumpulan Masyarakat Sadar Wisata adalah sebuah wadah perkumpulan bagi para profesional yang bergerak pada bidang kepariwisataan. MASATA merupakan organisasi yang didasari atas persamaan persepsi dan tidak memihak kepada salah satu organisasi sosial politik (AD/ART MASATA, 2020).

Dalam pertemuan tersebut para pengusaha membahas bagaimana kepariwisataan Indonesia terus berkembang dan maju. Membuat strategi pengembangan pariwisata budaya (Khotimah \& WilopoLuchman Hakim, 2017), rancang bangun sistem informasi geografi pariwisata (Yunita, Solle Karolina, Mamulak, Natalia Magdalena R., 2019).

Dengan kehadiran MASATA DPD Kalimantan Timur dapat membantu masyarakat desa dalam upaya untuk menentukan potensi yang ada di desa. Para anggota MASATA sudah disiapkan oleh Pengurus Pusat MASATA yakni dengan diadakan pelatihan-pelatihan yang diperlukan dalam upaya meningkatkan sumber daya manusia (SDM). Pelatihan pernah dilakukan oleh Dewan Pimpinan Pusat MASATA adalah pelatihan tentang sadar wisata, pelatihan dasar hukum pendirian desa wisata, pelatihan home stay, pelatihan sapta pesona, pelatihan pelayanan prima, pelatihan pemanduan wisata (guiding), pelatihan pelatihan pengolahan makanan sehat, pelatihan pengelolaan sampah. Dengan memiliki pengetahuan tersebut diharapkan anggota MASATA dapat membagikan ilmu dan pengalaman kepada masyarakat yang ada di desa wisata. DPD MASATA Kalimantan Timur mendapat mandat untuk pendampingan di desa Pela, Kabupaten Kutai Kartanegara, Mentawir Kecamatan Sepaku Kabupaten Penajam Paser Utara, Merasa Kecamatan Kelay Kabupaten Berau. Desa tersebut akan menjadi desa binaan dari DPD MASATA Kalimantan Timur. Organisasi DPD MASATA Kalimantan Timur akan mengadakan pendampingan serta pelatihan pondok wisata (Sudarmayasa, I Wayan, 2020), pelatihan makanan sehat (Uhai, Sabalius, 2020).

Selama ini penelitian lebih cenderung pada kelompok sadar wisata (pokdarwis), misalnya pemberdayaan pokdarwis (Hakim, Nasrul, Hayati, Suci, Lumbu, Aliyanti A., Nur Indah, Rahmawati \& Septiyana, 2017), Pokdarwis perlu menggali peluang ekonomi kreatif (Vuspitasari, Bendhikta Kikky Deffrinica, 2021), Pokdarwis sebagai penguat desa wisata (Purwanti, 2019), karena kelompok sadar wisata adalah kelompok masyarakat yang memiliki kepedulian terhadap desa wisata. Sekelompok warga tersebut saling membahu dalam upaya membangun desa mereka menjadi desa wisata yang pantas untuk dikunjungi oleh para pengunjung. Adapun penelitian ini adalah membahas tentang peran dari organisasi masyarakat sadar wisata (MASATA), apa perbedaan antara kelompok sadar wisata dengan masyarakat sadar wisata. Masyarakat sadar wisata adalah sekelompok orang yang memiliki kecintaan terhadap dunia pariwisata, kelompok sadar wisata adalah para pecinta pariwisata, para pengusaha pariwisata, organisasi pariwisata (Gabungan Industri Pariwisata Indonesia), para akademisi, pelaku pariwisata. Rumusan masalah dalam penelitian ini adalah apa peran dari organisasi Masyarakat Sadar Wisata (MASATA). Dengan penelitian ini diharapkan tidak perlu lagi memperdebatkan antara peran kelompok sadar wisata dengan peran masyarakat sadar wisata, keduanya saling mendukung dan kerja sama. Keduanya saling berbagi ilmu dan pengalaman, masyarakat sadar wisata membawa ilmu dan pengalaman lalu berbagi kepada kelompok sadar wisata.

\section{RUANG LINGKUP} berikut:

Ruang lingkup penelitian ini mencakup sebagai

1. Cakupan permasalahan dalam penelitian ini berfokus pada peran organisasi Masyarakat Sadar 
Wisata (MASATA) untuk mengembangkan desa wisata di Kalimantan Timur

2. Batasan penelitian ini hanya memfokuskan pada peran yang dilaksanakan oleh organisasi MASATA melalui orang-orang yang terlibat sebagai pengurus serta sebagai anggota dari organisasi MASATA. Berperan atau tidaknya sebuah organisasi akan bergantung dari anggota organisasi tersebut, apakah mereka berperan atau tidak dalam memajukan organisasi tersebut.

3. Dalam penelitian ini organisasi MASATA sangat berperan dalam upaya membantu masyarakat untuk membangun desa mereka sebagai desa wisata, membantu mempersiapkan SDM dalam menyukseskan dan memajukan desa wisata supaya lebih dikenal secara oleh masyarakat.

\section{BAHAN DAN METODE}

Berikut disajikan bahan dan metode dalam penelitian ini, yang terdiri dari dua bagian kajian yakni kajian teori dan metodologi penelitian.

\section{Peranan}

Dalam sebuah organisasi peran seorang pemimpin adalah sangat penting (Trioctavia, Jayanti, Hamid, Djamhur, 2016), (Gani, dkk, 2018). Pemimpin mampu memberikan motivasi kepada bawahannya (Pramono, 2013). Sedangkan Sutarto (2009:138-139) mengemukakan bahwa peran itu terdiri dari tiga komponen (Sutarto, 2009), yaitu:

1) Konsepsi peran, yaitu: kepercayaan seseorang tentang apa yang dilakukan dengan suatu situasi tertentu.

2) Harapan peran, yaitu: harapan orang lain terhadap seseorang yang menduduki posisi tertentu mengenai bagaimana ia seharusnya bertindak.

3) Pelaksanaan peran, yaitu: perilaku sesungguhnya dari seseorang yang berada pada suatu posisi tertentu. Kalau ketiga komponen tersebut berlangsung serasi, maka interaksi sosial akan terjalin kesinambungan dan kelancarannya.

Berdasarkan pendapat tersebut, maka dapat disimpulkan peran sebagai berikut:

1) Peran adalah pengaruh yang diharapkan dari seseorang dalam dan antar hubungan sosial tertentu.

2) Peran adalah pengaruh yang berhubungan dengan status atau kedudukan sosial tertentu.

3) Peran berlangsung bilamana seseorang melaksanakan hak - hak dan kewajiban kewajibannya sesuai dengan statusnya.

4) Peran terjadi bila ada suatu tindakan dan bilamana ada kesempatan yang diberikan (Lantaeda, Syaron Bbrigette Lengkiong \& Ruru, 2017).

Peranan organisasi MASATA adalah peran sebuah organisasi, namun demikian peran seorang pemimpin dalam organisasi MASATA juga menjadi sangat penting. Berperan atau tidaknya sebuah organisasi akan tergantung siapa yang memimpin organisasi tersebut.

\section{Organisasi}

Pengadaan sumber daya manusia yang berprestasi, inovatif dan mau bertumbuh adalah suatu hal yang mutlak harus dilakukan organisasi atau perusahaan di tengah zaman milenial ini, meskipun realisasinya tidaklah mudah. Untuk bisa menjadi pengurus dan anggota yang berprestasi dan inovatif, seorang pengurus dan anggota harus bisa menjadi pribadi yang lebih baik dan terpenuhi kebutuhan pertumbuhannya (growth needs). Organisasi dapat mendukung kebutuhan bertumbuh (growth needs) karyawan dengan memberikan kesempatan pada pengurus atau anggota organisasi untuk selalu mengembangkan diri dari waktu ke waktu (Yenti, Veny, Yuniawan, 2018). Kehadiran organisasi MASATA adalah membantu kelompok sadar wisata dalam upaya meningkatkan sumber daya manusia yakni baik itu pengurus maupun anggotanya. Oleh karena itu para pengurus organisasi MASATA yang memiliki latar belakang yang berbeda-beda harus diberikan pembekalan agar para pengurus organisasi MASATA mengerti dan memahami apa yang menjadi tugas dan tanggung jawabnya masing-masing, selain itu agar semuanya memiliki visi dan misi yang sama yakni sama-sama ingin membangun organisasi MASATA.

Jenis Penelitian ini menggunakan pendekatan secara kualitatif deskriptif, yakni suatu cara yang digunakan untuk memahami sifat-sifat dari suatu fenomena objek yang diteliti sehingga dapat diketahui dan analis pokok permasalahan yang muncul dan diambil alternatif pemecahannya (Creswell, 2013). Dalam penelitian kualitatif melibatkan upaya-upaya penting, seperti mengajukan pertanyaan-pertanyaan yang mendukung sehingga mendapatkan hasil yang diharapkan yakni ingin mengetahui peranan dari sebuah organisasi Masyarakat Sadar Wisata. Pertanyaan yang dimunculkan adalah apa peran dari organisasi MASATA, bagaimana penerapan AD/ART bagi para pengurus dan anggota MASATA, kegiatan apa saja yang dilakukan oleh organisasi MASATA dalam upaya meningkatkan SMD anggotanya. Apa kegiatan DPD MASATA Kalimantan Timur dalam kegiatan pengembangan potensi desa wisata yang ada di wilayah Kalimantan Timur, siapa saja yang boleh terlibat sebagai pengurus dan anggota organisasi MASATA.

Dalam penelitian ini yang menjadi informan kunci adalah Dewan Pimpinan Pusat MASATA yakni Bapak Panca S. Sarungu, Dewan Pimpinan Daerah Kalimantan Timur Bu Sri Agustina, serta Dewan Pimpinan Cabang MASATA di Kalimantan Timur, Ketua Kelompok Sadar Wisata (Pokdarwis) Kalimantan Timur yakni Pak Alimin. Adapun tujuan dari penelitian ini adalah untuk mengetahui peran organisasi Masyarakat Sadar Wisata dalam upaya mengembangkan potensi wisata di Kalimantan Timur. Sebagai bahan penguat dalam penelitian ini peneliti juga mempelajari anggaran dasar dan anggaran rumah tangga (AD/ART) Organisasi MASATA, dimana AD/ART adalah sebagai bahan 
utama untuk memahami dengan jelas peran, tugas dan tanggung jawab dari organisasi MASATA.

\section{PEMBAHASAN}

Organisasi Masyarakat Sadar Wisata (MASATA) adalah sebuah organisasi yang dibentuk oleh orang-orang yang peduli dengan dunia kepariwisataan, agar dapat memahami tentang organisasi Masyarakat Sadar Wisata (MASATA) adalah dengan memahami dan mengerti Anggaran Dasar dan Anggaran Rumah Tangga (AD/ART) organisasi tersebut. Pada bagian awal dari penulisan ini akan membahas tentang anggaran dasar dan anggaran rumah tangga (AD/ART) Organisasi MASATA

\subsection{Organisasi MASATA}

Perkumpulan Masyarakat Sadar Wisata (MASATA) peduli akan Pariwisata Indonesia dan mempunyai peran sangat strategis dalam upaya memperkokoh persatuan dan kesatuan bangsa, meningkatkan kesejahteraan masyarakat yang tergabung dalam anggota Perkumpulan, dan mendukung kehidupan ekonomi khususnya untuk kegiatan kepariwisataan, serta menunjang pembangunan Pariwisata Indonesia.

Berlandaskan dorongan oleh tanggung jawab akan masa depan bangsa dan Negara kesatuan Republik Indonesia, berpartisipasi aktif dalam mengisi kemerdekaan dan perwujudan cita-cita nasional dapat dilaksanakan dengan professional anggota, maka dibentuklah MASYARAKAT SADAR WISATA (MASATA), yang senantiasa berpegang teguh pada Anggaran Dasar Perkumpulan. Peranan organisasi Masyarakat Sadar Wisata (MASATA) adalah membantu masyarakat untuk menjadi lebih baik, memberikan pemahaman dan pengertian bagaimana mengelola sumber daya yang ada secara khusus di desa untuk dapat menghasilkan penghasilan atau pendapatan. Kehadiran organisasi MASATA diharapkan dapat membantu masyarakat dalam menghadapi berbagai masalah kehidupan di desa. Anggota organisasi MASATA yang terdiri dari berbagai latar belakang pendidikan dan berbagai pengalaman dalam berbagai bidang kehidupan semoga dapat memberikan sumbangsih untuk organisasi dan masyarakat.

Organisasi MASATA memiliki visi yakni Menjadi organisasi pelaku, pemerhati dan pencinta pariwisata Indonesia yang berkompeten dalam mendukung pariwisata berkelanjutan di Indonesia. Sedangkan misi yang ingin dijalankan adalah memberikan kontribusi nyata untuk mendukung sektor pariwisata menjadi penyumbang devisa terbesar bagi Indonesia. Memajukan pariwisata berbasis masyarakat dalam meningkatkan harkat, martabat, dan ekonomi khususnya daerah tujuan wisata di tingkat provinsi, kabupaten, dan kota. Membangun desa, kawasan, dan destinasi wisata dalam peningkatan ekonomi kreatif masyarakat. Sebagai narahubung dalam kepentingan kementerian dan lembaga antar pusat dan daerah khususnya dalam bidang pariwisata serta ekonomi kreatif. Membangun sinergitas dan kolaborasi antar asosiasi/organisasi/perkumpulan pariwisata di tingkat pusat dan daerah.

Dalam kehidupan bermasyarakat, berbangsa dan bernegara, perkumpulan ini berasaskan Pancasila sebagai satu-satunya ASAS. Adapun tujuan dan fungsi dari organisasi MASATA adalah terwujudnya profesionalisme anggota yang disiplin, berdedikasi dan memiliki loyalitas tinggi menuju kader bangsa yang berjiwa Pancasila dalam wadah Negara Kesatuan Republik Indonesia. Membantu usaha pemerintah dalam membina dan memajukan pariwisata nasional. Status dan bentuk organisasi. Pertama Status: Organisasi ini adalah organisasi yang bersifat pemberdayaan masyarakat pariwisata. Kedua Bentuk: Organisasi ini berbentuk kesatuan yang memiliki cabang-cabang di provinsi, kabupaten, dan kota di Indonesia. Pembinaan dan kegiatan organisasi. Pertama membina ketaatan anggota terhadap peraturan perundang-undangan dan organisasi. Kedua membina anggota dalam hal keterampilan dengan baik, benar dan bertanggung jawab. Ketiga meningkatkan kualitas sumber daya anggota, terutama dalam hal kepemimpinan dan keterampilan di bidang kepariwisataan. Keempat melakukan usaha-usaha yang dapat menunjang kelancaran program organisasi.

Kegiatan organisasi MASATA. Pertama menunjang program pemerintah dalam bidang pembangunan nasional dan membantu memelihara ketertiban, keamanan dan kenyamanan wisatawan. Kedua meningkatkan mutu pengetahuan dan profesionalisme anggota. Ketiga menjalin kerja sama dengan organisasi mana pun yang memiliki kepentingan untuk membangun industri pariwisata baik di dalam ataupun di luar negeri. Keempat memberi ruang kepada anggota dalam pengembangan kapasitas diri. Keanggotaan Organisasi MASATA, pertama anggota organisasi adalah Warga Negara Indonesia yang berprofesi kan diri dalam memberikan pelayanan jasa hospitaliti atau keramahtamahan kepada wisatawan serta memenuhi persyaratan sebagai anggota aktif yang ditentukan organisasi.

Kedua yang diterima menjadi anggota ialah mereka yang menerima visi dan misi serta bersedia menjalankan usaha organisasi. Ketiga anggota terdiri dari:

1. Anggota biasa, yaitu mereka yang terdaftar aktif sebagai anggota.

2. Anggota luar biasa, yaitu bekas anggota biasa dan mereka yang tidak termasuk dalam titik a.

3. Anggota kehormatan, yaitu mereka yang berjasa kepada organisasi.

4. Anggota penyokong, yaitu mereka yang bersedia membantu organisasi secara berkala dengan jumlah yang ditentukan oleh Dewan Pengurus Daerah/Cabang (AD/ART MASATA, 2020).

Susunan Organisasi MASATA secara bertingkat terdiri atas: pertama Dewan Pengurus Pusat, kedua Dewan Pengurus Daerah, ketiga Dewan Pengurus Cabang. Kekuasaan Organisasi MASATA Kekuasaan 
organisasi terdiri atas: pertama Musyawarah Nasional, kedua Dewan Pengurus Pusat, ketiga Musyawarah Daerah, keempat Dewan Pengurus Daerah, kelima Musyawarah Cabang, keenam Dewan Pengurus Cabang. Kepengurusan Organisasi MASATA: pertama Pengurus Pusat/Daerah/Cabang terdiri atas: a. Dewan PEMBINA Organisasi, b. Dewan PENGURUS. c. Tim Pendukung Organisasi. Kedua Dewan Pembina adalah unsur perorangan anggota Asosiasi Pendiri, di tingkatannya dan keterwakilan dari instansi kepariwisataan. a. Ketua Dewan Pembina Pusat adalah Menteri Pariwisata yang sementara menjabat. b. Ketua Dewan Pembina Daerah dan Cabang adalah kepala/wakil kepala daerah yang sementara menjabat. Ketiga Tim Pendukung Organisasi adalah unsur perorangan yang berasal dari Aparatur Sipil Negara (ASN). Keempat Dewan Pengurus adalah yang menjalankan tugas dan kegiatan Asosiasi. Kelima Tugas, wewenang, tanggung jawab Dewan Pendiri/ penasehat, Dewan Pembina Organisasi/Dewan Pengurus Pusat/Daerah/Cabang, diatur dalam Anggaran Rumah Tangga. Musyawarah dan rapat-rapat organisasi: pertama Musyawarah Asosiasi terdiri atas: Musyawarah Nasional/Daerah/Cabang. Kedua Rapat-rapat organisasi terdiri atas: a. Rapat Kerja Nasional/Daerah, b. Rapat Paripurna/Pusat/Daerah/Cabang, c. Rapat Pengurus Pusat/Daerah/Cabang, d. Rapat Koordinasi Pusat/Daerah/Cabang, e. Segala sesuatu yang berhubungan dengan Musyawarah dan Rapat-rapat Organisasi diatur dalam Anggaran Rumah Tangga.

Keuangan Organisasi MASATA: pertama Organisasi mempunyai kekayaan awal yang berasal dari para Pengurus Pusat MASATA, para Pengurus Daerah, dan para Pengurus Cabang MASATA. Selain dari kekayaan awal tersebut, kekayaan perkumpulan diperoleh dari:

1. Uang pendaftaran anggota,

2. Uang Iuran Anggota,

3. Kontribusi dari badan usaha yang didirikan oleh Organisasi,

4. Sumbangan sukarela / hibah,

5. Usaha-usaha lain yang sah sesuai dengan asas, visi dan misi organisasi serta tidak bertentangan dengan maksud dan tujuan perkumpulan serta perundang-undangan yang berlaku.

Kedua Kekayaan Perkumpulan hanya dapat dipakai untuk maksud dan tujuan yang sesuai dengan Anggaran Dasar Organisasi. Penggunaan kekayaan perkumpulan dan pengaturan pembukuan Organisasi semuanya diatur lebih lanjut dalam Anggaran Rumah Tangga Organisasi (AD/ART MASATA, 2020). Status keanggotaan Organisasi MASATA Keanggotaan MASATA terbuka bagi setiap Warga Negara Indonesia yang bergerak di dunia kepariwisataan dan telah memenuhi persyaratan yang telah ditetapkan oleh organisasi. Persyaratan keanggotaan Organisasi MASATA: pertama Anggota MASATA adalah setiap pelaku, pemerhati, dan pecinta pariwisata dan juga telah berpengalaman/berhubungan langsung ataupun tidak langsung dengan kepariwisataan yaitu:

1. Agen Perjalanan Wisata (Pemilik, Tour, Reservasi \& Ticketing, Admin),

2. Hotel (Pemilik, Sales \& Marketing, FO, PR, Banquet),

3. Airlines (Pemilik, Sales \& Marketing, Reservasi \& Ticketing, Cargo),

4. Restaurant (Pemilik, Sales \& Marketing), e. LSUP (Auditor Pariwisata) atau LSP (Assessor), f. Pramuwisata,

5. Event Organizer,

6. Akademisi dan Praktisi

7. Bidang Usaha/Organisasi/Komunitas yang bergerak dibidang pariwisata.

Kedua Anggota yang telah memenuhi persyaratan akan diterbitkan e-KTA (Kartu Tanda Anggota) melalui aplikasi MASATA. Ketiga Dalam hal tertentu Pengurus Daerah/Cabang dapat mengajukan Anggota Kehormatan di tingkatan masing-masing dengan persetujuan Pengurus Pusat.

Susunan Pengurus Daerah Organisasi MASATA: pertama Dewan Pembina Organisasi Daerah paling sedikit lima orang dan maksimal sepuluh anggota yang terdiri dari unsur forkopimda, pemuka agama, tokoh adat, dan tokoh pemuda. Kedua Tim Pendukung Organisasi Daerah paling sedikit beranggotakan lima sampai tujuh orang yang terdiri dari Aparatur Sipil Negara (ASN) aktif yang mengajukan diri untuk berkontribusi namun tidak dapat menjabat sebagai Dewan Pengurus Daerah. Adapun hubungan Tim Pendukung Organisasi dengan Dewan Pengurus Daerah ialah bersifat koordinasi. Ketiga Susunan Dewan Pengurus Daerah adalah sebagai berikut:

1. Ketua Wilayah,

2. Wakil Ketua I Bidang Organisasi,

3. Wakil Ketua II Bidang Program Kerja,

4. Sekretaris Wilayah,

5. Wakil Sekretaris Wilayah,

6. Bendahara Wilayah,

7. Wakil Bendahara Wilayah,

8. Kepala Bidang Organisasi dan Hubungan antar Cabang,

9. Kepala Bidang Usaha dan Dana,

10. Kepala Bidang Pemberdayaan Komunitas Pariwisata dan UMKM,

11. Kepala Bidang Penelitian dan Pengembangan.

12. Kepala Bidang Penguatan Hukum dan HAM,

13. Kepala Bidang Media Informasi dan Hubungan Masyarakat,

14. Kepala Bidang Pelestarian Budaya dan Pariwisata Berkelanjutan,

15. Kepala Bidang Kebersihan, Kesehatan, dan Keselamatan (CHS).

Keempat Susunan tersebut di atas dapat disesuaikan dengan kondisi dan anggota di wilayah masing-masing. Kriteria pengurus Organisasi MASATA, pertama Persyaratan Umum Pengurus: 
1. Anggota MASATA,

2. Mampu berorganisasi dan siap bertanggung jawab atas jabatannya,

3. Bersedia menjadi Pengurus yang dinyatakan secara tertulis,

4. Bersedia memperpanjang keanggotaan selama periode kepengurusannya.

5. Untuk Aparatur Sipil Negara hanya dapat menjabat sebagai tim pendukung dan tidak dapat menjadi Dewan Pengurus.

Kedua Persyaratan Khusus Ketua dan Sekretaris DPP/DPD/DPC:

1. Memiliki hubungan yang baik dengan instansi dan asosiasi terkait kepariwisataan di wilayah/daerahnya.

2. Memiliki komitmen tinggi dalam memimpin organisasi dibuktikan dengan surat pernyataan komitmen.

3. Berbadan sehat dan tidak pernah dipenjara/bermasalah secara hukum. d. Berjiwa pemimpin dibuktikan dengan surat pengalaman organisasi.

4. Mandiri secara finansial.

Ketiga Kriteria Ketua Umum dan Sekretaris

Jenderal Dewan Pengurus Pusat (DPP):

1. Memenuhi Persyaratan Umum Pengurus dan Persyaratan khusus.

2. Bersedia untuk berdomisili di Ibukota Negara dan sekitarnya selama periode kepengurusannya,

3. Bersedia hadir pada rapat-rapat Dewan Pengurus Pusat.

4. Tidak menjadi Pengurus di organisasi sejenisnya,

5. Berwawasan Nasional.

Keempat Kriteria Ketua dan Sekretaris Dewan Pengurus Daerah (DPD):

1. Memenuhi Persyaratan Umum Pengurus dan Persyaratan khusus.

2. Berdomisili tetap di Wilayahnya masing-masing,

3. Tidak sedang menjadi/menjabat pengurus di organisasi sejenisnya.

Kelima Kriteria Ketua dan Sekretaris Dewan Pengurus Cabang (DPC):

1. Memenuhi Persyaratan Umum Pengurus dan Persyaratan khusus.

2. Berdomisili tetap di Wilayahnya masing-masing,

3. Tidak menjadi pengurus di organisasi sejenisnya. Musyawarah Pengurus Daerah DPD Kalimantan Timur yakni pertama Musyawarah Daerah merupakan forum kekuasaan tertinggi dalam tata kehidupan organisasi di tingkat daerah. Kedua Wewenang Musyawarah Daerah:

1. Mengadakan penilaian terhadap laporan pertanggung jawaban Dewan Pengurus Daerah.

2. Menetapkan Program Kerja Daerah, yang merupakan penjabaran Program Kerja Nasional.

3. Memilih dan menetapkan Ketua dan Sekretaris Dewan Pengurus Daerah.
4. Memilih dan menetapkan Anggota Dewan Pembina Organisasi Daerah.

5. Memilih dan menetapkan anggota Tim Pendukung Organisasi Daerah.

Ketiga Penyelenggaraan:

1. Musyawarah Daerah diselenggarakan oleh Dewan Pengurus Daerah.

2. Musyawarah Daerah diselenggarakan lima tahun sekali, kecuali ada hal-hal khusus.

3. Dihadiri oleh setengah ditambah satu $(1 / 2 n+1)$ jumlah Dewan Pengurus Cabang untuk yang memiliki cabang di daerahnya.

4. Keputusan Musyawarah Daerah diupayakan secara musyawarah untuk mufakat. Bila hal tersebut tidak tercapai, maka keputusan didasarkan pada musyawarah suara terbanyak, yaitu disetujui 2/3 (dua per tiga) jumlah peserta yang memiliki hak suara.

5. Musyawarah Daerah dalam keadaan khusus disebut Musyawarah Daerah Luar Biasa, hanya dapat diselenggarakan atas permintaan minimal dua pertiga (2/3) dari jumlah Kepengurusan Cabang.

Keempat Peserta Musyawarah Daerah:

1. Utusan Dewan Pengurus Cabang sebanyak 3 orang

2. Peninjau Cabang sebanyak 3 orang,

3. Dewan Pengurus Daerah,

4. Dewan Pembina Organisasi Daerah,

5. Tim Pendukung Organisasi,

6. Utusan / Narasumber DPP ,

7. Undangan

\subsection{DPD MASATA Kalimantan Timur}

DPD MASATA Kalimantan Timur dilantik pada tanggal 30 Januari 2021. Pada saat pelantikan DPD Kalimantan Timur dihadiri oleh Ketua Umum Dewan Pimpinan Pusat MASATA Bapak Panca R. Sarungu, sekaligus melantik DPD dan DPC MASATA Indonesia. Pelantikan DPD dan DPC Indonesia diselenggarakan secara hybrid (Offline dan Online) secara Offline diadakan di Kantor Gubernur Kalimantan Timur. Pelantikan DPD MASATA Kalimantan Timur dihadiri oleh Wakil Gubernur Kalimantan Timur Bapak H. Hadi Mulyadi, S.Si, M.Si, , Kepala Dinas Pariwisata Kalimantan Timur Ibu Dra. Sri Wahyuni, MPP, Kepala Dinas Kominfo Bapak H.M FAISAL, S.Sos., M.Si. DPD MASATA Kalimantan Timur diketuai oleh Ibu Sri Agustina, SE. Wakil Ketua Bapak Anwar Kholis. Sekretaris DPD MASATA Kalimantan Timur adalah Bapak Ariantho Arruan, Spd.

DPD MASATA Kalimantan Timur adalah sebuah organisasi baru, namun demikian harapan dari berbagai pihak sangat tinggi dengan kehadiran MASATA.

Program Kerja DPD Kalimantan Timur adalah melanjutkan program DPP MASATA yakni melaksanakan pembinaan terhadap desa wisata dan 
pendampingan untuk Usaha Kecil Menengah (UKM) atau Usaha Mikro, Kecil dan Menengah (UMKM).

DPC MASATA Kalimantan Timur, adapun DPC MASATA Kalimantan Timur yang sudah terbentuk adalah DPC MASATA Samarinda, ketua DPC MASATA Samarinda adalah Efendi Almari. DPC MASATA Penajam Paser Utara (PPU), ketua DPC MASATA PPU adalah Nur Ariyanti, ST. DPC MASATA Kutai Kartanegara (KUKAR), ketua DPC MASATA KUKAR adalah Ahmad. DPC MASATA Bontang, ketua DPC MASATA Bontang adalah Hariyadi, S. Par. DPC MASATA Balikpapan, ketua DPC MASATA Balikpapan adalah Moeso Novianto. Beberapa kabupaten yang ada di Kalimantan Timur akan memiliki DPC MASATA. Dengan kehadiran DPC MASATA Kalimantan Timur diharapkan dapat membantu Pemerintah secara khusus Dinas Pariwisata dalam usaha mengembangkan desa wisata. Selain itu juga terlibat dalam masyarakat desa wisata yakni pendampingan Sumber Daya Manusia (SDM). Adapun pendampingan yang dilakukan adalah mempersiapkan SDM bagian depan yakni masyarakat yang terlibat langsung dengan tamu yang akan datang, pelatihan yang dilakukan dengan materi tentang sapta pesona, sadar wisata, pelayanan prima, kesehatan dan keselamatan kerja, pelayanan home stay bagi pengelola home stay.

\subsection{Peranan Organisasi DPD MASATA Kaltim}

Dalam menjalankan misinya DPD MASATA Kalimantan Timur melaksanakan Program DPP MASATA yang bekerja sama dengan Kementerian Pariwisata dan Ekonomi Kreatif. Yakni pendampingan desa wisata.

\section{Pendampingan Desa Wisata}

Pendampingan desa wisata yang dilaksanakan oleh DPD MASATA Kalimantan Timur dan bekerja sama dengan DPC MASATA Kalimantan Timur. Pendampingan pertama adalah desa-desa yang telah ditunjuk oleh Kementerian Pariwisata dan Ekonomi Kreatif untuk di Kalimantan Timur adalah empat desa yang masuk dalam kategori rintisan ada satu yakni Desa Tani Aman yang berada di Kecamatan Loa Janan Kabupaten Kutai Kartanegara, sedangkan yang sudah maju ada tiga yakni Desa Pela di Kecamatan Kota Bangun Kabupaten Kutai Kartanegara, Desa Mentawir di Kecamatan Spaku Kabupaten Penajam Paser Utara (PPU), Desa Meraya Kecamatan Kelay Kabupaten Berau. Namun demikian DPP MASATA memberikan kesempatan kepada DPD dan DPC memilih salah satu desa sebagai desa wisata dengan gaya MASATA.

Organisasi MASATA memang baru terbentuk namun para anggota MASATA memiliki pengalaman dalam bidang kepariwisataan. Agar dapat mencapai misi dan visi organisasi MASATA dalam pendampingan desa wisata dan pendampingan UMKM maka diperlukan melakukan berbagai pelatihan atau berbagi pengalaman untuk para anggota yang akan ke lapangan untuk pendampingan desa wisata. Dewan Pimpinan Daerah
MASATA Kalimantan Timur yang diketuai oleh Sri Agustina berusaha membentuk Dewan Pimpinan Cabang (DPC) MASATA yang ada di Kabupaten dan Kota di Kalimantan Timur. Dengan terbentuknya DPC MASATA di masing-masing Kabupaten dan Kota akan lebih mudah mengetahui potensi-potensi wisata dari masing-masing daerah tersebut.

Pendampingan yang dilakukan oleh Organisasi MASATA harus memperhatikan arahan dari DPP MASATA dari Kelompok percepatan desa wisata yang diketuai oleh Bapak K. Swabawa (K. SWABAWA, 2021) beberapa hal yakni:

1. Potensi

Potensi adalah bentuk sumber daya atau kemampuan yang cukup besar, namun kemampuan tersebut belum tersingkap dan belum diaktifkan. Arti lainnya dalam pengertian ini bahwa potensi adalah kekuatan terpendam yang belum dimanfaatkan, bakat tersembunyi, atau keberhasilan yang belum diraih pada hal kita mempunyai kekuatan untuk mencapai hal tersebut. Pendataan awal ketika melakukan survey potensi desa wisata sebagai desa wisata. Data semua potensi yang ada di desa tersebut. Mulai dari alam, seni tari, seni suara, seni ukir, produk olahan dari masyarakat desa tersebut.

2. Peluang

Setelah dilakukannya pendataan potensi desa tersebut langkah selanjutnya adalah menentukan apa saja yang akan menjadi peluang usaha atau kegiatan yang dapat dilakukan di desa tersebut sehingga dapat menghasilkan pemasukan bagi desa.

Masyarakat sadar wisata dan kelompok sadar wisata melaksanakan pendataan peluang apa saja yang terdapat pada desa tersebut, baik itu peluang usaha yakni hasil olahan produk lokal maupun adanya tempat wisata yang layak untuk dikunjungi.

3. Produk

Aspek Produk Desa Wisata, menurut Viki Maukemana (Maukemana, 2019) adapun aspek desa wisata adalah sebagai berikut:

1) Authenticity

Keaslian dari produk desa wisata ini sangatlah penting karena akan menjadi branding sekaligus ciri khas yang bisa digunakan dalam promosi desa wisata. Desa harus menemukan potensi yang otentik sehingga dapat memunculkan sebuah objek wisata yang dapat dikembangkan dan berbeda dengan objek yang sudah ada.

\section{2) Local Tradition}

Tak hanya aspek authentic saja, aspek produk desa wisata lainnya adalah local tradition atau tradisi lokal desa. Karena sudah dilakukan turun temurun, maka tradisi lokal ini dianggap sudah melekat pada masyarakat dan bisa dianggap menjadi salah satu kearifan lokal yang beragam di Indonesia.

Aspek produk desa wisata dalam hal keunikan dari kearifan lokal atau tradisi masyarakat setempat ini bisa menjadi nilai jual yang menarik bagi wisatawan baik dalam negeri maupun luar negeri. 


\section{3) Attitude and Values}

Aspek produk desa wisata yang ketiga adalah sikap dan nilai yang disebut juga sebagai attitude and values. Mengapa ini menjadi penting? Karena masyarakat harus siap terhadap perubahan yang akan datang pada desanya. Akan ada banyak orang luar desa yang lalu lalang datang dan berkunjung dengan berbagai budaya dan kebiasaan yang mereka bawa.

Sebagai masyarakat desa wisata harus memperhatikan segala kemungkinan yang akan terjadi, oleh karena itu masyarakat desa harus mempersiapkan diri mereka secara baik. Memiliki sikap yang peduli terhadap budaya.

4) Conservation and Carrying Capacity

Perubahan akan datang, baik dalam segi penduduk desa yang mungkin akan bertambah, pembangunan, berkurangnya lahan dan lain-lain. Yang perlu diingat adalah bagaimana hal tersebut harus tetap berpedoman pada aspek produk desa wisata yang mengarah pada nilai konservasi dan daya dukung (Maukemana, 2019).

5) Pelayanan

Pelayanan adalah suatu aktivitas atau serangkaian aktivitas yang bersifat tidak kasat mata (tidak dapat diraba) yang terjadi sebagai akibat adanya interaksi antara konsumen dengan karyawan atau hal-hal lain yang disediakan oleh perusahaan pemberi pelayanan yang dimaksudkan untuk memecahkan permasalahan konsumen atau pelanggan.

4. Profit atau laba

Pelayanan yang telah dilakukan selanjutnya adalah untuk memperhatikan jika desa tersebut dilakukan pengelolaan oleh Kelompok Sadar Wisata (POKDARWIS) bekerja sama dengan Badan Usaha Milik Desa (Bumdes) apakah dapat menghasilkan profit atau laba atau tidak, oleh karena itu perlu membuat studi kelayakan bisnis, dengan dibuatnya studi kelayakan bisnis dapat memperkirakan apakah dengan dibuka desa tersebut sebagai desa wisata dapat memberikan dampak yang baik untuk masyarakat atau tidak. Peran POKDARWIS dalam pengembangan atraksi wisata di desa (Putra, 2013), peran POKDARWIS dalam pengembangan pariwisata (Putrawan, Putu Edi, 2019). Peran penting yang diembankan oleh Kelompok Sadar Wisata akan menjadi ringan jika dibantu oleh Organisasi Masyarakat Sadar Wisata. Profit akan ada untuk desa wisata jika semua pihak saling kerja sama, saling membantu dan saling memberikan manfaat untuk masyarakat.

\section{KESIMPULAN}

Implikasi akhirnya penelitian ini adalah bahwa peranan Organisasi Masyarakat Sadar Wisata (MASATA) sangat dibutuhkan oleh kelompok sadar wisata (POKDARWIS). Kehadiran organisasi MASATA sebagai pendukung kegiatan Kepariwisataan Kementerian Pariwisata dan Ekonomi Kreatif sangat diperlukan dan diharapkan dalam upaya meningkatkan dan mengembangkan potensi-potensi wisata yang ada di desa, dengan demikian untuk memastikan bahwa desa tersebut layak disebut desa wisata.

Pendampingan desa wisata adalah sebuah keharusan di mana untuk mempersiapkan masyarakat desa dalam upaya mengembangkan potensi yang ada di desa tersebut. Dengan adanya kehadiran organisasi Masyarakat Sadar Wisata (MASATA) akan sangat berperan dalam upaya membantu masyarakat desa dalam usaha merintis desanya menjadi desa wisata.

\section{SARAN}

Penelitian ini hanya terkonsentrasi pada peranan organisasi MASATA untuk pengembangan desa wisata di Kalimantan Timur. Peran organisasi MASATA bagi kelompok sadar wisata adalah saling membantu satu sama lainnya, saling berbagi pengalaman dari para pengurus MASATA dalam upaya meningkatkan kemampuan kelompok sadar wisata.

Penelitian lanjutan dari penelitian ini adalah lebih pada kegiatan-kegiatan yang dilaksanakan oleh organisasi MASATA, apakah kegiatan yang dilakukan organisasi MASATA telah memberikan dampak bagi kelompok sadar wisata (Pokdarwis). Apakah para anggota kelompok sadar wisata yang diberikan pelatihan oleh organisasi MASATA dapat menjalankan kegiatan tersebut dengan baik, apakah program yang dijalankan sudah sesuai seperti yang diharapkan oleh desa wisata tersebut.

\section{DAFTAR PUSTAKA}

Abdillah. (2020). Pengertian Desa Menurut Para Ahli Serta Fungsi Ciri-Ciri Desa. Rumusrumus.Com. https://rumusrumus.com/pengertian-desa/

Andiani, Nyoman Dini, N. M. A. W. (2017). Model Edukasi Pariwisata bagi Kelompok Sadar Wisata di Kabupaten Buleleng. SENARI 2017, Seminar Nasional Riset Inovatif 2017.

Bona P. Benazir, R. R. R. \& P. L. (2017). Sustainable Tourism Communication Through POKDARWIS (Kelompok Sadar Wisata) In West Bandung District. The 1st International Conference on Social Sciences, 461.

Creswell, J. W. (2013). Research Design Pendekatan Kualitatif, Kuantitatif dan Mixed (Edisi ketiga). Pustaka Belajar.

Dirjen Pengembangan Destinasi Pariwisata. (2012). Pedoman Pokdarwis. Kementerian Pariwisata dan Ekonomi Kreatif.

Evita, R., Sirtha, I. N., \& Sunarta, I. N. (2012). Dampak Perkembangan Pembangunan Sarana Akomodasi Wisata Terhadap Pariwisata Berkelanjutan di Bali. Jurnal Ilmiah Pariwisata, 109-222. http://ojs.unud.ac.id/index.php/jip/article/view/3684

Gani, Nur Asni, Utama, Rony Edward, S. S. (2018). Analisis Peranan Pemimpin Dalam Membentuk Budaya Organisasi Rumah Sakit Swasta, Jakarta. Http://Research-Report.Umm.Ac.Id/, Working 
Papers of Innovation in Economics. http://researchreport.umm.ac.id/index.php/LIPFEBUMM/article/v iew/2655

Hakim, Nasrul, Hayati, Suci, Lumbu, Aliyanti A., Nur Indah, Rahmawati, N., \& Septiyana, L. (2017). Pemberdayaan Kelompok Sadar Wisata (POKDARWIS) Dalam Mengembangkan Ekowisata Desa Gunung Rejo Kecamatan Way Ratai. Dedikasi: Pengabdian Kepada Masyarakat, Vol. 1 No.(semua bidang ilmu), 235.

K. SWABAWA. (2021). Pokja Percepatan Desa Wisata Mandiri DPP MASATA Bersama Kemenparekraf RI.

Karini, Zulia, Hendra Marcos, Y. M. I. (2018). Kelompok Sadar Wisata (POKDARWIS) Desa Wisata Limbasari Kecamatan Bobotsari Kabupaten Purbalingga. J-ABDIPAMAS, Vol. 2, No(Semua bidang ilmu), 73 .

Khotimah, K., \& WilopoLuchman Hakim. (2017). Strategi Pengembangan Destinasi Pariwisata Budaya (Studi Kasus Pada Kawasan Situs Trowulan Sebagai Pariwisata Budaya Unggulan di Kabupaten Mojokerto). Jurnal Administrasi Bisnis, $41 \quad$ No.1(Administrasi), 56. http://administrasibisnis.studentjournal.ub.ac.id/ind ex.php/jab/article/view/1657

Lantaeda, Syaron Bbrigette Lengkiong, F. D. J., \& Ruru, J. M. (2017). Peran Badan Perencanaan Pembangunan Daerah Dalam Penyusunan RPJMD Kota Tomohon. Jurnal Administrasi Publik, Vol.4 No.(administrasi publik), 2-3. https://ejournal.unsrat.ac.id/index.php/JAP/article/v iew/17575

Maukemana, V. (2019). Empat Aspek Kunci Produk Wisata. Desabisa.Com. https://www.desabisa.com/empat-aspek-kunciproduk-wisata/

Nurmayasari, Dhea, M. (2017). Strategi Kelompok Sadar Wisata (POKDARWIS) Dalam Pengembangan Pariwisata di Desa Canggu Kecamatan Badas Kabupaten Kediri. Publika, Vol. 5, No(Ilmu Administrasi Negara),

1. https://jurnalmahasiswa.unesa.ac.id/index.php/publi $\mathrm{ka} /$ article/view/18711/17073

Pramono, H. N. (2013). Peranan Pemimpin Dalam Memotivasi Karyawan (Stusi Pada CV. Tigi Cyber Computer Malang). Jurnal Administrasi Bisnis, Vol. 6 No.(Administrasi Bisnis), 1. http://administrasibisnis.studentjournal.ub.ac.id/ind ex.php/jab/article/view/301

Purwanti, I. (2019). Strategi Kelompok Sadar Wisata Dalam Penguatan Desa Wisata. JISIP, Vol. 8, No(Jurnal Ilmu Sosial dan Ilmu Politik), 101.

Putra, T. R. (2013). Peran Pokdarwis dalam Pengembangan Atraksi Wisata di Desa Wisata Tembi, Kecamatan Sewon-Kabupaten Bantul. Jurnal Pembangunan Wilayah Dan Kota, 9 No. 3(Pengembangan wilayah dan kota), 225. https://doi.org/https://doi.org/10.14710/pwk.v9i3.65 22

Putrawan, Putu Edi, A. M. J. (2019). Peran Kelompok Sadar Wisata (POKDARWIS) Dalam Pengembangan Pariwisata di Desa Munduk Kecamatan Banjar Kabupaten Buleleng. Locus Majalah Ilmiah Fisip, 11 No. 2(Ilmu Sosial dan Ilmu Politik), 40. https://ejournal.unipas.ac.id/index.php/LOCUS/arti cle/view/279

Putri, Tiara Nur Tsofyani, Hartuti Purnaweni, M. S. (2015). Implementasi Program Kelompok Sadar Wisata (POKDARWIS) di Kelurahan Kandri, Kecamatan Gunungpati, Kota Semarang. Journal of Public Policy and Management Review, Vol. 04, N(J. Public Policy Manag. Rev.), 1. https://doi.org/10.14710/jppmr.v4i1.7232

Rahayu, A. S. (2018). Pengantar Pemerintahan Desa. Sinar Grafika.

Sarungu, P. R. (2021). Organisasi Masyarakat Sadar Wisata. Manuskrip Wawancara.

Sudarmayasa, I Wayan, I. W. L. N. K. (2020). Pelatihan Pengelolaan Pondok Wisata Bagi Kelompok Sadar Wisata Desa Pela, Kecamatan Kota Bangun, Kabupaten Kutai Kartanegara. Jurnal Sebatik, 23 No. $\quad 1$, 51-58. https://jurnal.wicida.ac.id/index.php/sebatik/article/ view/903

Sutarto. (2009). Dasar-Dasar Organisasi. UGM Press.

Trioctavia, Jayanti, Hamid, Djamhur, M. D. M. (2016). Peranan Pemimpin Dalam Mengembangkan Budaya Organisasi (Studi Kasus Pada PT. ASuransi Jiwasraya (Persero) Malang Regional Office). Jurnal Administrasi Bisnis, Vol. 40 No(Administrasi $\quad$ Bisnis), 150. http://administrasibisnis.studentjournal.ub.ac.id/ind ex.php/jab/article/view/1594

Uhai, Sabalius, I. W. S. (2020). Pelatihan Pembuatan Makanan Sehat Untuk Program Diet Alami Yang Bergizi Untuk Kelompok Ibu-Ibu di Samarinda Program Kemitraan Masyarakat. Jurnal Sebatik, 24 No. 2, 222-227. https://jurnal.wicida.ac.id/index.php/sebatik/article/ view/990

Utami, Asri Nurul, A. Z. R. (2017). Pelaksanaan Program Kampanye Sadar Wisata dan Sapta Pesona melalui Pelestarian Kelompok Sadar Wisata ( Pokdarwis ) di Kelurahan Kandri Kecamatan Gunungpati Kota Semarang. Journal Of Public Policy And Management Review, Vol.06 No.(J. Public Policy Manag. Rev.). https://doi.org/10.14710/jppmr.v6i2.16139

Vuspitasari, Bendhikta Kikky Deffrinica, S. V. B. S. (2021). Menggali Peluang Ekonomi Kreatif Melalui Potensi Desa Suka Maju Kabupaten Bengkayang. Jurnal Sebatik, Vol. 25, N(Multidisiplin ilmu), 181. https://doi.org/https://doi.org/10.46984/sebatik.v25i 1.1132 
Wahyuni, D. (2018). Strategi Pengembangan Pemberdayaan Masyarakat Dalam Pengembangan Desa Wisata Nglanggeran, Kabupaten Gunung Kidul. Aspirasi, Vol. 09 No(Jurnal MasalahMasalah Sosia), 83.

Wijaya, Surya Arif, Zulkarnain, S. (2016). Proses Belajar Kelompok Sadar Wisata (POKDARWIS) Dalam Pengembangan Kampoeng Ekowisata. Jurnal Pendidikan Nonformal, Vol. XI, N(semua bidang ilmu), 88 .

Yenti, Veny, Yuniawan, A. (2018). Analisis Pengaruh Motivasi Pertumbuhan dan Organization-Based Self EStem Terhadap Kinerja Karyawan Melalui Komitmen Organisasional Sebagai Variabel Intervening. Diponegoro Journal of Management, Vol. 7 , No. https://ejournal3.undip.ac.id/index.php/djom/article/ view/22501

Yunita, Solle Karolina , Mamulak, Natalia Magdalena R., P. B. (2019). Rancang Bangun Sistem Informasi Geografis Tempat Pariwisata di Pulau Timor
Berbasis Web. Jurnal Sebatik, 23 No. 1(Multi disiplin ilmu), 224. https://jurnal.wicida.ac.id/index.php/sebatik/article/ view/473/178

\section{UCAPAN TERIMA KASI}

Terima kasih peneliti ucapkan yang tak terhingga kepada Pak Panca S. Sarungu sebagai Ketua Umum Dewan Pimpinan Pusat (DPP) MASATA. sekretaris umum DPP MASATA Pak Ricky, Bu Sri Agustina Ketua Dewan Pimpinan Daerah Kalimantan Timur, Pak Ariantho Arruan Sekretaris DPD MASATA Kalimantan Timur, Pak Alimin sebagai Ketua Umum Kelompok Sadar Wisata (Pokdarwis) Kalimantan Timur. Ketua Jurusan Pariwisata Pak I Wayan Lanang, serta Ketua Program Studi Usaha Perjalanan Wisata Pak Muhammad Fauzan Noor, semua Dosen-dosen Jurusan Pariwisata, serta Manajemen POLNES. 